\title{
Investigating the reliability of shear strength equations in TS500 and ACI318-19
}

\author{
M. Fethi Gullu*iD, F. Saleh Mohammed \\ Harran University, Department of Civil Engineering, Şanlıurfa, Turkey
}

\begin{abstract}
Lateral loads (e.g., wind and earthquake loads) lead to shear forces as well as the axial loads and moments on the structural members. Although reinforced concrete (RC) columns are commonly assumed as slender members and are not expected to represent shear dominant response characteristics, experimental studies have shown that even slender columns have shear responses. Hence, in seismic design, the shear strength of columns must be accurately predicted to prevent shear failure of columns. Validation of Requirements for Design and Construction of RC structures (TS500) for shear strength calculation of RC columns by a broad range of test data has been neglected in the literature. In this study, 57 test results of rectangular RC columns were collected from available laboratory tests to verify the shear strength calculation approach in TS500. Additionally, a statistical comparison of results obtained from TS500 with Building Code Requirements for Structural Concrete (ACI318-19) has been studied in this study. Maximum shear strength of RC columns obtained from the previously studied test data was compared with shear strengths calculated according to TS 500 as well as with the results obtained from ACI318-19. Comparisons are scrutinized in terms of shearspan-to-depth ratios, reinforcing ratios, material properties, and stirrup spacing as well as axial load ratios applied on top of the columns. Investigation of existing design equations reveals a significant difference in prediction. This study will be extended by adding further test results from the literature to provide crucial comments about the shear strength calculation of RC columns in TS500.
\end{abstract}

\section{Keywords}

Concrete; Column; Shear strength; Design codes; Assessment

Received: 08 February 2021; Accepted: 30 April 2021

ISSN: 2630-5763 (online) (C) 2021 Golden Light Publishing All rights reserved.

\section{Introduction}

Reinforced concrete (RC) column design features affect the response of structural systems under vertical and horizontal loads. Column axial load capacity and moment capacity are designed to provide adequate resistance to the internal forces developed due to the vertical loads (e.g., dead load and live load) and horizontal loads (e.g., earthquake load). In the capacity design approach, shear failure was inhibited due to having a brittle response. With the implementation of a performance-based design approach in current seismic design codes, the nonlinear behavior of frame systems has been severely studied to investigate the energy dissipation capacity under earthquake loads. It is a fact that in performance-based design since flexural behavior is ductile compared to shear behavior, shear strength of frame elements (i.e., columns and beams) is designed to prevent shear failure in those elements. Besides, prediction of the shear strength

\footnotetext{
Corresponding author

Email: fethigullu@harran.edu.tr
} 
of RC columns and prevention of shear failure is deemed critical in seismic assessment of existing reinforced concrete structures. Although RC columns have intentionally been allowed to reach their flexural strength in nonlinear analysis, the shear strength of RC columns is not permitted to be exceeded in both performance-based and capacity design approaches because exceeding shear strength will be ended up with brittle failure, leading to unavoidable results during an earthquake ground motion.

In the literature, large numbers of experimental research have been studied on investigating the behavioral response characteristic of RC columns. However, for predicting the shear strength of RC columns, there are limited modeling approaches and equations in the literature. In 1973, Wight and Sozen [3] conducted an experimental study to describe the failure modes for RC columns subjected to reversed-cyclic loading. An analytical model based on the material properties was developed for simulation of the behavioral characteristics of the column specimens. Priestley et. al. [4] proposed an equation to predict the shear strength of rectangular and circular RC columns. The model was developed with consideration of the contribution of concrete, a truss mechanism for simulation of transverse reinforcement, and an arch mechanism for representing axial load. The equation was validated against test results from the literature. It was presented in the study that the developed equation provides a reliable correlation with test results. The model needed further validation with a wide range of experimental results. Sasani [5] used experimental results of 89 column specimens and the mechanics for shear force transfer to introduce a new model for predicting the shear strength of RC columns. Also, the author used only test results for predicting drift capacity ratios of columns. The proposed model covers shear-span-to-depth ratio, axial compressive load, and displacement ductility effects on the shear strength of columns. The model was found to be reliable in predicting the shear strength of $\mathrm{RC}$ column specimens if $2 / 3$ of strength was provided by transverse reinforcement. Recently, Aval et. al.
[6] proposed new equations to estimate the shear strength of rectangular RC short columns using statistical techniques and gene expression programming. The authors validated their equations using test results and the model they have developed in ABAQUS [7] software as well as compared their equations with the shear strength equations in ACI318-11 [8] and EC2 [9] design codes. The equation presented reasonable estimations in shear strength of short columns, however; the equation was only validated using test results of short rectangular RC columns. Ketabdari et. al. [10] employed gene expression programming and particular swarm optimization algorithms with numerical models analyzed by ABAQUS [7] for estimation of shear strength of short circular RC columns. Developed equations were compared with ACI318-14 [11] and ASCE-ACI 426 [12] and the authors stated that the equations were more reliable compared to design codes included in the study. Most recently, Kakavand et. al. [13] proposed a data-driven model for estimation of the shear strength of the rectangular and circular RC columns. Although they have developed a new model for predicting the shear strength of $\mathrm{RC}$ columns, they did not perform any analysis for checking the reliability of existing design codes, e.g., TS500 [1].

The shear strength of RC columns plays an important role in seismic design codes since columns are part of the frame systems and provide lateral strength and stiffness for the buildings especially in the absence of structural walls. Hence, the shear strength of RC columns needs to be predicted with high accuracy in seismic design codes. For evaluating the shear strength of RC columns, current design codes consider the contribution of concrete and transverse reinforcing bars. In the presence of flexure and axial force, the contribution of those components is simply added together to calculate the shear strength of columns. A review of the studies in literature has shown that statistical validation of shear strength calculation approach proposed in Requirements for Design and Construction of RC structures (TS500 [1]) and comparison of TS 500 [1] with Building Code 
Requirements for Structural Concrete (ACI 318-19 [2]) was not investigated. Within the scope of this study test results of $57 \mathrm{RC}$ column specimen was used for validation of the shear strength equation in TS500 [1] and comparison of TS500 [1] shear strength prediction with the equation in ACI318-19 [2] was presented.

\section{Methodology}

\subsection{Shear strength calculation}

Design codes, used for comparison of test results, have been summarized in this section. TS500 [1] and ACI318-19 [2] shear strength equations with the definition of the parameters in the equations have been presented. It is worth mentioning that, within the scope of this study, the shear strength of $\mathrm{RC}$ column specimens is only calculated in the experimental loading direction so that it can be comparable with test results collected from the literature.

\subsubsection{Shear strength equation in TS 500}

The shear strength equation used in TS500 [1] has been summarized herein. Shear strength $\left(V_{r}\right)$ is explained as the summation of the shear strength provided by concrete $\left(V_{c}\right)$ and by transverse reinforcement $\left(V_{s}\right)$ as shown in the equation below;

$V_{r}=V_{c}+V_{w}$

$V_{r}=0.8\left(0.65 f_{c t} b_{w} d\left(1+\gamma \frac{P_{d}}{A_{c}}\right)\right)+\left(\frac{A_{s w} f_{y w} d}{s}\right)$

where $f_{c t}$ is the axial tensile strength of concrete, $b_{w}$ is the web width of the cross-section, $d$ is the effective depth of the cross-section, $P_{d}$ is the applied axial load, $A_{c}$ is the web cross-sectional area, $A_{s w}$ is the total transverse bar area between longitudinal spacing, $f_{y w}$ is the yield strength of transverse reinforcement, $s$ is the vertical spacing between transverse reinforcement. The applied axial load $P_{d}$ is positive for both tensile and compressive forces; however, $\gamma$ should be taken as 0.07 if the applied axial load is compressive and whereas it should be taken as -0.3 under tension.

\subsubsection{Shear strength equation in ACI 318-19}

Similar to TS500 [1] in ACI 318-19 [2], the shear strength $\left(V_{n}\right)$ equation is calculated as the summation of the contribution of concrete $\left(V_{c}\right)$ and transverse reinforcement $\left(V_{s}\right)$ as shown in Eq. 3. The contribution of transverse reinforcement to the shear strength is calculated equal with TS 500 [1]; however, the involvement of concrete to the shear strength calculation in ACI318-19 [2] differs from TS500 [1] due to considering a limit for minimum shear reinforcement area $\left(A_{v, \text { min }}\right)$.

$V_{n}=V_{c}+V_{s}$

In the case of $A_{v} \geq A_{v, \min }$, concrete contribution to the shear strength can be calculated as follows;

$$
\left[0.17 \lambda \sqrt{f_{c}{ }^{\prime}}+\frac{P_{u}}{6 A_{g}}\right] b_{w} d
$$

whereas for the case of $A_{v}<A_{v, \min }$

$$
\left[0.66 \lambda_{s} \lambda\left(\rho_{l}\right)^{1 / 3} \sqrt{f_{c}{ }^{1}}+\frac{P_{u}}{6 A_{g}}\right] b_{w} d
$$

The equation for minimum shear reinforcement of $\mathrm{RC}$ columns is the greater of the following relationships;

$$
\begin{aligned}
& A_{v, \text { min }}=0.062 \sqrt{f_{c}{ }^{\prime}} \frac{b_{w} s}{f_{y t}} \\
& A_{v, \text { min }}=0.35 \frac{b_{w} s}{f_{y t}}
\end{aligned}
$$

In the above equations, $\lambda$ is the coefficient for concrete modification (for normal weight concrete it is equal to 1.0), $\lambda_{s}$ is the size effect factor (an empirical factor related to the effective depth of the cross-section), $\rho_{l}$ is the longitudinal reinforcement ratio, $P_{u}$ is the applied axial load, $A_{g}$ is the gross area of concrete cross-section, $f_{c}{ }^{\prime}$ is the specified concrete compressive strength, $b_{w}$ is the web width of the cross-section, $d$ is the effective depth of the cross-section, $s$ is the vertical spacing between transverse reinforcement, and $f_{y t}$ is the yield strength of transverse reinforcement. 


\subsection{Description of collected data}

To achieve the aim of this study, 57 rectangular RC column specimens have been collected from ten different experimental programs, having different geometric properties, shear-span-to-depth ratios, axial load levels, reinforcement configurations, and material properties. First, column specimens were selected from the experimental research carried out by Kokusho [14] at the Building Research Institute (BRI) in Tsukuba, Japan. Two of the RC column specimens from the study were used herein with only different longitudinal reinforcement ratios each other. Kokusho and Fukuhara [15] at Tokyo Industrial University continued the experimental study of Kokusho [14] by eight specimens, two of which were used for evaluation of TS500 [1] and ACI318-19 [2] within the scope of this study. These two column specimens were differentiated again by the longitudinal reinforcement ratios. Ikeda at Yokohama National University [16] conducted an experimental study with $38 \mathrm{RC}$ column specimens having identical geometric dimensions with the specimens investigated by Kokusho [14]. Seven column specimens, which differentiate with varying axial load levels, longitudinal reinforcement ratios, and material properties, were chosen from the experimental program for evaluation of design codes.

In the following years, Umemura and Endo [17] tested 24 specimens having similar cross-sectional properties with the column specimens tested by Kokusho [14] and Ikeda [16]. Eight of which have been used for the assessment of the design codes in terms of shear strength equations. They have equal axial load levels except that the specimen UM-214 has approximately twice the axial load of other specimens in the experimental program. Material properties, transverse and longitudinal reinforcement ratios, and the longitudinal spacing of transverse reinforcements differentiated between the column specimens tested by Umemura and Endo [17]. Wight and Sozen [3] carried out an experimental study on the RC column specimens to investigate the observed failure modes. Fifteen of which were used in this study with the crosssectional dimensions of $152 \times 305 \mathrm{~mm}$, longitudinal reinforcement ratio of 0.0245 , and transverse reinforcement ratio between 0.0033 and 0.0150 , as well as with the axial load ratios ranged from $0.0 A_{g} f_{c}{ }^{\prime}$ to $0.15 A_{g} f_{c}{ }^{\prime}$. Ohue et. al. [18] prepared an experimental program for simulation of doublecurvature loading conditions on eleven RC column specimens. Two of which were chosen to compare the TS500 [1] and ACI318-19 [2] shear strength predictions. The column specimens have identical properties with an exception of having different longitudinal reinforcement ratios. Saatcioglu and Ozcebe [19] conducted an experimental study on fourteen RC column specimens using a cantilever experimental configuration for simulation of the response of the columns between the basement and inflection point. Seven of which were used herein for comparing test observations with the numerical results obtained from the design codes. The main differences between the selected specimens are the spacing between stirrups and the transverse reinforcement ratio. Only one of the selected specimens has zero axial load applied while the remaining six specimens have a constant axial load level of $600 \mathrm{kN}$. Esaki [20] used a similar experimental program with Ohue et. al. [18] to investigate the effect of vertical spacing in transverse reinforcement and axial load levels on the RC columns response. The authors used four column specimens having identical longitudinal reinforcement ratios and material properties. These specimens were designed to fail in shear following the flexural yielding. Lynn et. al. [21] carried out experimental studies on RC columns with constant geometric dimensions, different reinforcement configurations under constant axial load levels either $0.12 f_{c}^{\prime} A_{g}$ or $0.35 f_{c}^{\prime} A_{g}$. Normal-weight aggregate concrete with compression strength varying between $25 \mathrm{MPa}$ and $33 \mathrm{MPa}$ was the concrete material properties of the tested $\mathrm{RC}$ column specimens. The failure modes of test specimens were flexure, shear, lap-splice, and collapse under applied axial load. Finally, three column specimens tested by Sezen and Moehle [22] were used for further assessment of the design codes. The main objective of the experimental study was to observe and analyze the effect of the 
axial load levels on the failure mechanism of RC columns. Reversed cyclic loading was continued in all experiments until specimens were no longer able to accommodate axial loads.

Geometric properties, shear-span-to-depth ratios, reinforcement configurations, and axial load levels of column specimens, used for assessment of shear strength equations in code provisions, as well as with experimentally observed average shear strengths are presented in Table 1. For calculating the average shear strength of the column specimens, lateral load-displacement relations were drawn for all specimens investigated within the scope of this study. Average shear strengths of test specimens are obtained by getting the average of the maximum and minimum lateral-load capacities of test results for each column specimen.

\section{Comparison of design code predictions with measured shear strength capacites}

Confirmation of shear strength equations in TS500 [1] and ACI318-19 [2] are presented in this section through the comparison of design code predictions with test results. Shear strength equations in TS500 [1] and ACI318-19 [2] have been used for the calculation of shear strengths of RC columns having the material and geometric properties summarized in Table 1.

Fig. 1 and Fig. 2 show the contribution of concrete and transverse reinforcement to the shear strength estimations of each specimen according to TS500 [1] and ACI318-19 [2], respectively. Besides, the effect of concrete and transverse reinforcement on the shear strength are summed for comparison of design code shear strength predictions with experimental results. Shear strength predictions according to the equation in ACI318-19 [2] is higher for about all specimens except two of 57 specimens than the theoretical strength calculated using the equation in TS500 [1] in terms of contribution of concrete to the shear strength. Transverse reinforcement contribution to shear strength estimations in TS500 [1] is almost equal to predictions in ACI318-19 [2] for all specimens, indicating that the diversity between the shear strength predictions of TS500 [1] and ACI318-19 [2] is due to the variations in concrete contribution. It is obvious that theoretical shear strength predictions according to ACI318-19 [2] are commonly greater than shear strength predictions obtained via the equation in TS500 [1], manifesting that the concrete contribution for shear strength is higher in the equation of ACI318-19 [2].

Reliability of design codes has also been investigated in terms of shear-span-to-depth ratio, axial load ratio, concrete compressive strength, transverse reinforcement yield strength, longitudinal reinforcement ratio, and transverse reinforcing bar spacing to focus on their effect on the shear strength equations in design codes (Figs. 3-5). Design code calculation results are scrutinized in terms of shear-span-to-depth ratio due to being one of the main characteristics of RC columns to predict the behavioral response, whether it is sheardominant or flexural-dominant. The higher level of spear span values results in higher moment values in the plastic hinge zone of RC columns for the constant shear force, leading to flexural cracking and degradation in shear strength. For shear-spanto-depth ratios below 3.0, the ratio of test results to predicted values for 23 column specimens shows that TS500 [1] underestimated the test results with a mean value of 1.01 whereas ACI318-19 [2] overestimated measured results with a mean value of 0.85 (Fig. 3a). Shear-span-to-depth ratios above 3.0, design code estimations for $34 \mathrm{RC}$ column specimens have been investigated. The average value of shear strengths predicted by TS500 [1] and ACI318-19 [2] to test results is 0.86 and 0.75 , respectively, demonstrating that for higher shearspan-to-depth ratios, both design codes overestimate shear strengths of RC columns (Fig. $3 a)$. Fig. $3 b$ shows the ratio of test results to design code predictions according to axial load ratios of RC column specimens investigated in the study. Most of the specimens studied herein have axial load ratios below $35 \%$ with a mean value of 0.90 for TS500 [1] shear strength predictions and with a mean value of 0.79 for ACI318-19 [2] shear strength calculations. 
Table 1. Characteristics of RC column specimens

\begin{tabular}{|c|c|c|c|c|c|c|c|c|c|c|c|c|c|c|}
\hline & Specimen & $b_{w}$ & $h$ & $d$ & & $s$ & $f_{y w}$ & $f_{c}^{\prime}$ & $\rho_{l}$ & $\rho_{t}$ & \# of & $\phi_{t}$ & $P$ & $\mathrm{~V}_{\text {Test,avg }}$ \\
\hline & ID Name & $(\mathrm{mm})$ & $(\mathrm{mm})$ & $(\mathrm{mm})$ & a/d & $(\mathrm{mm})$ & $(\mathrm{MPa})$ & (MPa) & $(\%)$ & $(\%)$ & legs & $(\mathrm{mm})$ & $\overline{A_{g} f_{c}^{\prime}}$ & $(\mathrm{kN})$ \\
\hline \multirow{2}{*}{ Kokusho [14] } & $1 \quad$ Ko-372 & 200 & 200 & 170 & 2.94 & 100 & 352 & 20 & 1.33 & 0.33 & 2 & 6.5 & 0.196 & 74.7 \\
\hline & 2 Ко-373 & 200 & 200 & 170 & 2.94 & 100 & 352 & 20.4 & 1.98 & 0.33 & 2 & 6.5 & 0.192 & 87.1 \\
\hline \multirow{2}{*}{$\begin{array}{l}\text { Kokusho and } \\
\text { Fukuhara [15] }\end{array}$} & $\begin{array}{ll}3 & \text { Кo-452 }\end{array}$ & 200 & 200 & 170 & 2.94 & 100 & 316 & 22 & 2.84 & 0.33 & 2 & 6.5 & 0.447 & 108.5 \\
\hline & $4 \quad$ Ко-454 & 200 & 200 & 170 & 2.94 & 100 & 316 & 22 & 3.8 & 0.33 & 2 & 6.5 & 0.447 & 108.0 \\
\hline \multirow{7}{*}{ Ikeda [16] } & $\begin{array}{ll}5 & \text { Ik-43 }\end{array}$ & 200 & 200 & 173 & 2.89 & 100 & 560 & 19.6 & 2 & 2.8 & 2 & 6.1 & 0.102 & 86.5 \\
\hline & $6 \quad$ Ik-44 & 200 & 200 & 173 & 2.89 & 100 & 560 & 19.6 & 2 & 2.8 & 2 & 6.1 & 0.102 & 69.4 \\
\hline & 7 Ik-45 & 200 & 200 & 173 & 2.89 & 100 & 560 & 19.6 & 2 & 2.8 & 2 & 6.1 & 0.199 & 80.9 \\
\hline & $8 \quad \mathrm{Ik}-46$ & 200 & 200 & 173 & 2.89 & 100 & 560 & 19.6 & 2.66 & 2.8 & 2 & 6.1 & 0.199 & 79.8 \\
\hline & 9 Ik-62 & 200 & 200 & 173 & 2.89 & 100 & 476 & 19.6 & 1.97 & 2.8 & 2 & 6.1 & 0.102 & 57.0 \\
\hline & $10 \mathrm{Ik}-63$ & 200 & 200 & 173 & 2.89 & 100 & 476 & 19.6 & 2 & 2.8 & 2 & 6.1 & 0.199 & 70.6 \\
\hline & $11 \mathrm{Ik}-64$ & 200 & 200 & 173 & 2.89 & 100 & 476 & 19.6 & 2 & 2.8 & 2 & 6.1 & 0.199 & 70.0 \\
\hline \multirow{8}{*}{$\begin{array}{l}\text { Umemura and } \\
\text { Endo [17] }\end{array}$} & 12 UM-205 & 200 & 200 & 180 & 3.33 & 100 & 324 & 17.6 & 2 & 0.28 & 2 & 6 & 0.223 & 68.5 \\
\hline & 13 UM-207 & 200 & 200 & 180 & 2.22 & 100 & 324 & 17.6 & 2 & 0.28 & 2 & 6 & 0.223 & 106.0 \\
\hline & 14 UM-214 & 200 & 200 & 180 & 3.33 & 200 & 324 & 17.6 & 2 & 0.14 & 2 & 6 & 0.557 & 80.3 \\
\hline & 15 UM-220 & 200 & 200 & 180 & 2.22 & 120 & 648 & 33 & 1 & 0.11 & 2 & 4 & 0.119 & 78.7 \\
\hline & 16 UM-231 & 200 & 200 & 180 & 2.22 & 100 & 524 & 15 & 1 & 0.13 & 2 & 4 & 0.262 & 48.9 \\
\hline & 17 UM-232 & 200 & 200 & 180 & 2.22 & 100 & 524 & 13.1 & 1 & 0.13 & 2 & 4 & 0.300 & 57.6 \\
\hline & 18 UM-233 & 200 & 200 & 180 & 2.22 & 100 & 524 & 14 & 1 & 0.13 & 2 & 4 & 0.280 & 67.5 \\
\hline & 19 UM-234 & 200 & 200 & 180 & 2.22 & 100 & 524 & 13.1 & 1 & 0.13 & 2 & 4 & 0.300 & 68.4 \\
\hline \multirow{15}{*}{$\begin{array}{l}\text { Wight and } \\
\text { Sozen [3] }\end{array}$} & $20 \mathrm{~W} 40-033 \mathrm{aE}$ & 152 & 305 & 255 & 3.44 & 127 & 345 & 34.7 & 2.45 & 0.32 & 2 & 6.3 & 0.117 & 98.8 \\
\hline & $21 \mathrm{~W} 40-033 \mathrm{aW}$ & 152 & 305 & 255 & 3.44 & 127 & 345 & 34.7 & 2.45 & 0.32 & 2 & 6.3 & 0.117 & 98.3 \\
\hline & $22 \mathrm{~W} 40-048 \mathrm{E}$ & 152 & 305 & 255 & 3.44 & 89 & 345 & 26.1 & 2.45 & 0.5 & 2 & 6.3 & 0.147 & 98.9 \\
\hline & $23 \mathrm{~W} 40-048 \mathrm{~W}$ & 152 & 305 & 255 & 3.44 & 89 & 345 & 26 & 2.45 & 0.5 & 2 & 6.3 & 0.148 & 98.0 \\
\hline & $24 \mathrm{~W}-40-033 \mathrm{E}$ & 152 & 305 & 255 & 3.44 & 127 & 345 & 33.6 & 2.45 & 0.32 & 2 & 6.3 & 0.114 & 92.1 \\
\hline & $25 \mathrm{~W} 40-033 \mathrm{~W}$ & 152 & 305 & 255 & 3.44 & 127 & 345 & 33.6 & 2.45 & 0.32 & 2 & 6.3 & 0.114 & 102.5 \\
\hline & $26 \mathrm{~W} 25-033 \mathrm{E}$ & 152 & 305 & 255 & 3.44 & 127 & 345 & 33.6 & 2.45 & 0.46 & 2 & 6.3 & 0.071 & 85.3 \\
\hline & $27 \mathrm{~W} 25-033 \mathrm{~W}$ & 152 & 305 & 255 & 3.44 & 127 & 345 & 33.6 & 2.45 & 0.46 & 2 & 6.3 & 0.071 & 91.1 \\
\hline & $28 \mathrm{~W} 0-048 \mathrm{~W}$ & 152 & 305 & 255 & 3.44 & 64 & 345 & 25.9 & 2.45 & 0.46 & 2 & 6.3 & 0 & 98.2 \\
\hline & 29 W40-067E & 152 & 305 & 255 & 3.44 & 64 & 345 & 33.4 & 2.45 & 0.7 & 2 & 6.3 & 0.115 & 97.3 \\
\hline & $30 \mathrm{~W} 40-067 \mathrm{~W}$ & 152 & 305 & 255 & 3.44 & 64 & 345 & 33.4 & 2.45 & 0.7 & 2 & 6.3 & 0.115 & 96.6 \\
\hline & 31 W40-147E & 152 & 305 & 255 & 3.44 & 64 & 317 & 33.5 & 2.45 & 1.5 & 2 & 9.5 & 0.115 & 117.8 \\
\hline & $32 \mathrm{~W} 40-147 \mathrm{~W}$ & 152 & 305 & 255 & 3.44 & 64 & 317 & 33.5 & 2.45 & 1.5 & 2 & 9.5 & 0.115 & 117.6 \\
\hline & 33 W40-092E & 152 & 305 & 255 & 3.44 & 102 & 317 & 33.5 & 2.45 & 1.5 & 2 & 9.5 & 0.115 & 118.5 \\
\hline & $34 \mathrm{~W} 40-092 \mathrm{~W}$ & 152 & 305 & 255 & 3.44 & 102 & 317 & 33.5 & 2.45 & 1.5 & 2 & 9.5 & 0.115 & 116.9 \\
\hline \multirow{2}{*}{ Ohue et. al. [18] } & 35 2D16RS & 200 & 200 & 176 & 2.27 & 50 & 316 & 32 & 2.01 & 0.48 & 2 & 5.6 & 0.143 & 96.7 \\
\hline & 36 4D13RS & 200 & 200 & 176 & 2.27 & 50 & 316 & 30 & 2.65 & 0.48 & 2 & 5.6 & 0.153 & 105.9 \\
\hline \multirow{6}{*}{$\begin{array}{c}\text { Saatcioglu and } \\
\text { Ozcebe [19] }\end{array}$} & $37 \mathrm{U} 1$ & 350 & 350 & 305 & 3.28 & 150 & 470 & 43.6 & 3.31 & 0.3 & 2 & 10 & 0 & 263.7 \\
\hline & $38 \mathrm{U} 2$ & 350 & 350 & 305 & 3.28 & 150 & 470 & 30.2 & 3.21 & 0.3 & 2 & 10 & 0.162 & 267.1 \\
\hline & $39 \mathrm{U} 3$ & 350 & 350 & 305 & 3.28 & 75 & 470 & 34.8 & 3.31 & 0.6 & 2 & 10 & 0.141 & 269.0 \\
\hline & $40 \mathrm{U} 4$ & 350 & 350 & 305 & 3.28 & 50 & 470 & 32 & 3.31 & 0.9 & 2 & 10 & 0.153 & 314.6 \\
\hline & $41 \mathrm{U} 6$ & 350 & 350 & 305 & 3.28 & 65 & 425 & 37.3 & 3.31 & 0.85 & 6 & 6.5 & 0.131 & 333.5 \\
\hline & 42 U7 & 350 & 350 & 305 & 3.28 & 65 & 425 & 39 & 3.31 & 0.85 & 6 & 6.5 & 0.126 & 334.6 \\
\hline \multirow{4}{*}{ Esaki [20] } & $43 \mathrm{H}-2-1-3$ & 200 & 200 & 175 & 2.29 & 40 & 365 & 23 & 2.65 & 0.71 & 2 & 6 & 0.347 & 114.4 \\
\hline & 44 H-2-1-5 & 200 & 200 & 175 & 2.29 & 50 & 365 & 23 & 2.65 & 0.57 & 2 & 6 & 0.209 & 106.7 \\
\hline & 45 НT-2-1-3 & 200 & 200 & 175 & 2.29 & 60 & 365 & 20.2 & 2.65 & 0.71 & 3 & 6 & 0.347 & 115.4 \\
\hline & 46 HT-2-1-5 & 200 & 200 & 175 & 2.29 & 75 & 365 & 20.2 & 2.65 & 0.57 & 3 & 6 & 0.208 & 106.6 \\
\hline \multirow{8}{*}{ Lynn et. al. [21] } & 47 3CLH18 & 457.2 & 457.2 & 394 & 3.74 & 457.2 & 400 & 26.9 & 3 & 0.07 & 2 & 9.5 & 0.089 & 266.5 \\
\hline & 48 3SLH18 & 457.2 & 457.2 & 394 & 3.74 & 457.2 & 400 & 26.9 & 3 & 0.07 & 2 & 9.5 & 0.089 & 243.5 \\
\hline & 49 2CLH18 & 457.2 & 457.2 & 397 & 3.71 & 457.2 & 400 & 33.1 & 2 & 0.07 & 2 & 9.5 & 0.073 & 237.7 \\
\hline & 50 2SLH18 & 457.2 & 457.2 & 397 & 3.71 & 457.2 & 400 & 33.1 & 2 & 0.07 & 2 & 9.5 & 0.073 & 231.0 \\
\hline & $512 \mathrm{CMH} 18$ & 457.2 & 457.2 & 397 & 3.71 & 457.2 & 400 & 25.5 & 2 & 0.07 & 2 & 9.5 & 0.284 & 305.5 \\
\hline & 52 3СМH18 & 457.2 & 457.2 & 394 & 3.74 & 457.2 & 400 & 27.6 & 3 & 0.07 & 2 & 9.5 & 0.262 & 300.0 \\
\hline & 53 3CMD12 & 457.2 & 457.2 & 394 & 3.74 & 304.8 & 400 & 27.6 & 3 & 0.17 & 3.4 & 9.5 & 0.262 & 355.5 \\
\hline & 54 3SMD12 & 457.2 & 457.2 & 394 & 3.74 & 304.8 & 400 & 25.5 & 3 & 0.17 & 3.4 & 9.5 & 0.284 & 360.5 \\
\hline \multirow{3}{*}{$\begin{array}{c}\text { Sezen and } \\
\text { Moehle [22] }\end{array}$} & 55 2CLD12 & 457.2 & 457.2 & 393.7 & 3.74 & 304.8 & 476 & 21.1 & 2.5 & 0.17 & 3.4 & 9.5 & 0.151 & 308.6 \\
\hline & 56 2CHD12 & 457.2 & 457.2 & 393.7 & 3.74 & 304.8 & 476 & 21.1 & 2.5 & 0.17 & 3.4 & 9.5 & 0.605 & 330.0 \\
\hline & 57 2CLD12M & 457.2 & 457.2 & 393.7 & 3.74 & 304.8 & 476 & 21.8 & 2.5 & 0.17 & 3.4 & 9.5 & 0.146 & 264.3 \\
\hline
\end{tabular}




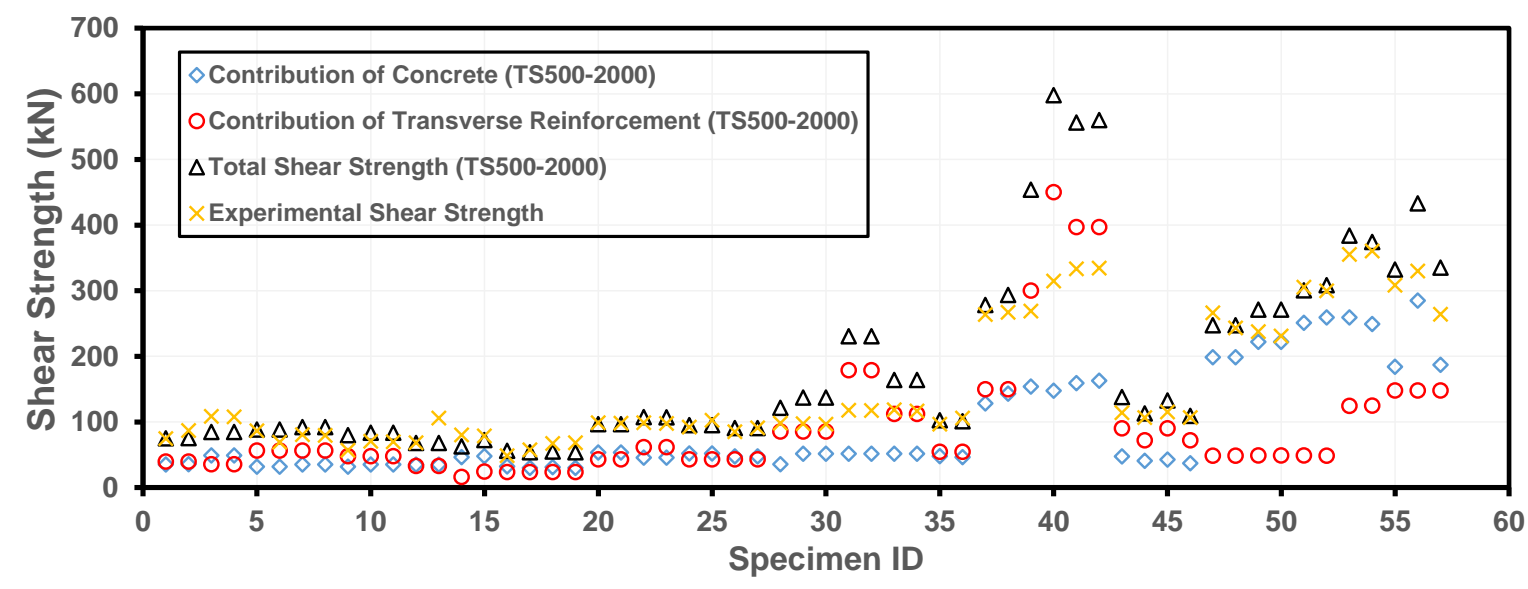

Fig. 1. Shear strength predictions of RC columns with TS500 [1]

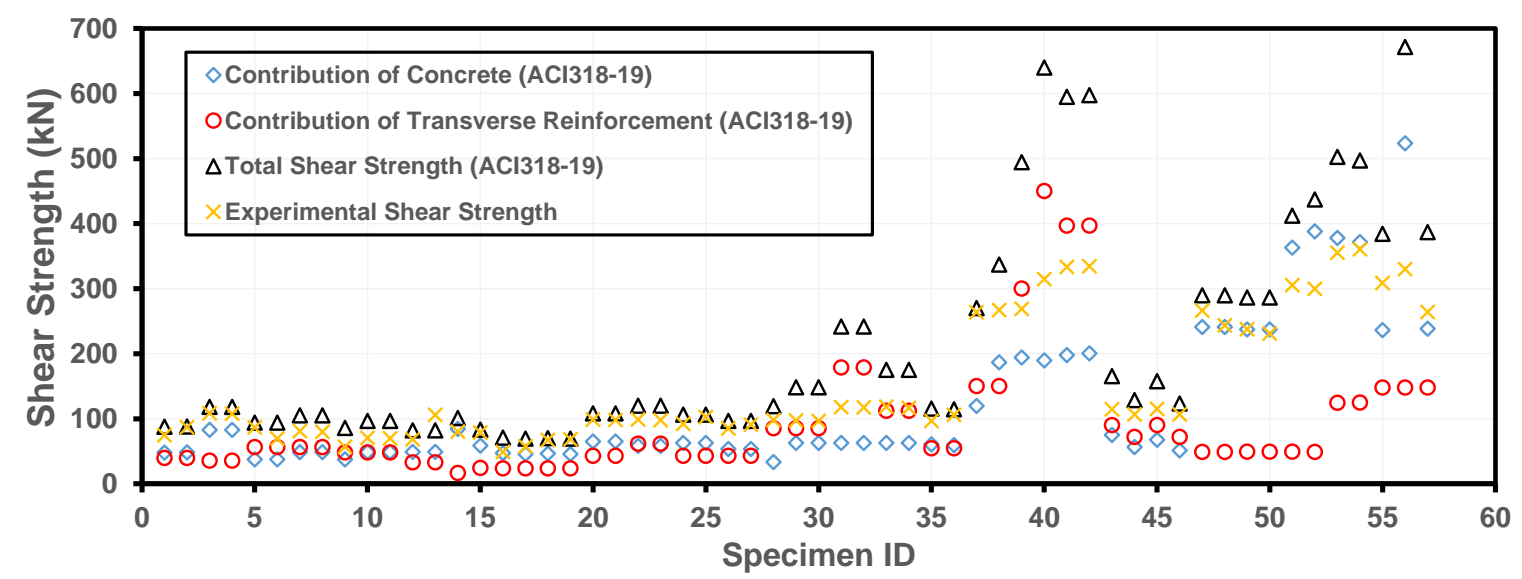

Fig. 2. Shear strength predictions of RC columns with ACI318-19 [2]

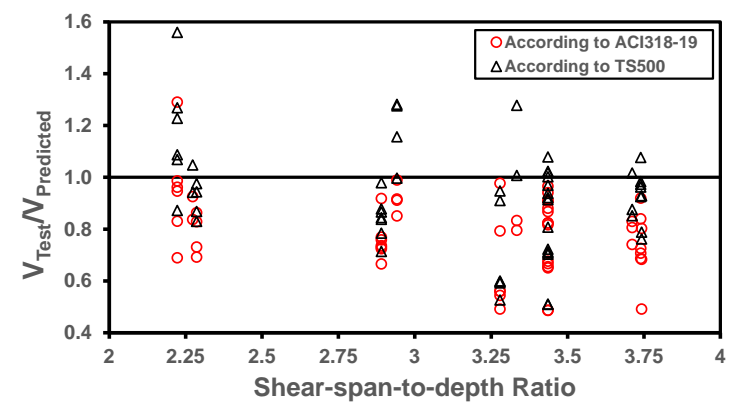

(a) shear-span-to-depth ratio

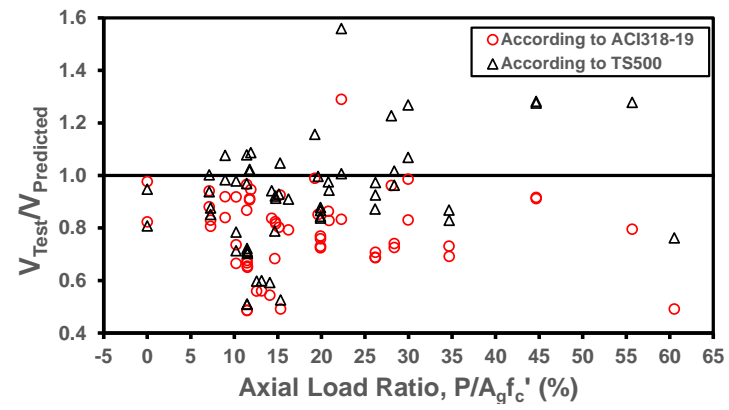

(b) axial load ratio

Fig. 3. Comparison of shear strengths of RC columns 


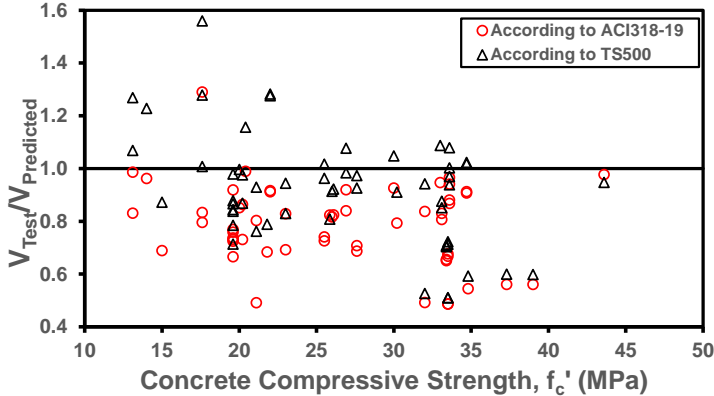

(a) concrete compressive strength

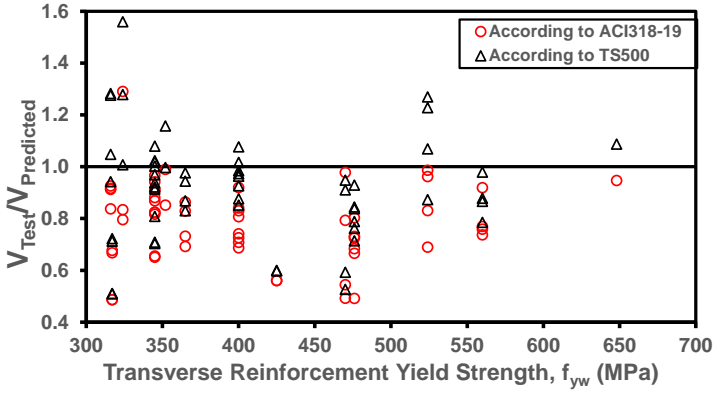

(b) transverse reinforcement yield strength

Fig. 4. Comparison of shear strengths of RC columns

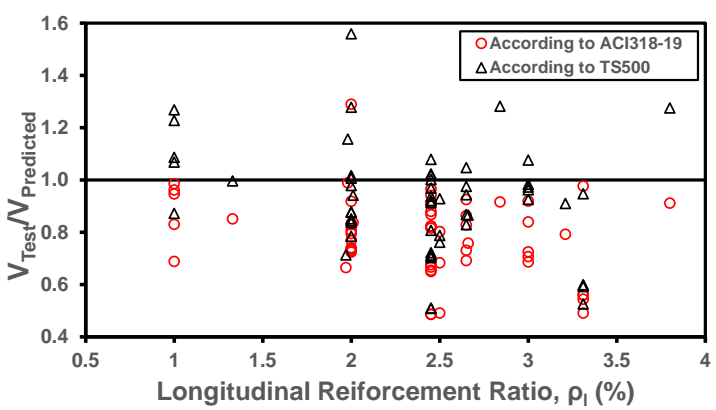

(a) longitudinal reinforcement ratio

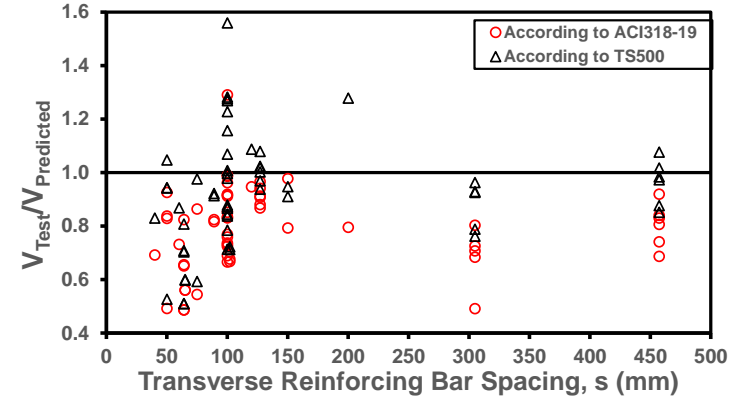

(b) transverse reinforcing bar spacing

Fig. 5. Comparison of shear strengths of RC columns

For the specimens having axial load ratios higher than 35\%, TS500 [1] underestimated the test results for shear strength of columns whereas ACI318-19 [2] overestimated the measured shear strength of column specimens

Further reliability of design codes has been conducted by comparing measured and predicted shear strength of RC columns in terms of concrete compressive strength and transverse reinforcement yield strength (Fig. 4). For all column specimens investigated in this study, concrete compressive strength is lower than $50 \mathrm{MPa}$. Since concrete compressive strength of approximately $30 \mathrm{MPa}$ is mostly used in the site, measured to predicted ratios are evaluated into two groups. For the specimens having concrete compressive strength equal to or lower than $30 \mathrm{MPa}$, the mean value of test results to TS500 [1] predictions is 0.99 , representing the reliability of TS500 [1] estimations for column specimens having lower concrete compressive strength. However, the measured to predicted ratio is 0.81 in the predictions of $\mathrm{ACI} 318-19$ [2] revealing that estimations of ACI318-19 [2] overestimated shear strengths of column specimens with concrete compressive strength below or equal to 30MPa. Both design code predictions overestimated measured shear strengths for column specimens with concrete compressive strength higher than $30 \mathrm{MPa}$. Transverse reinforcement yield strength, which is a multiplier for the stirrup contribution to shear strength equations, is one of the main parameters in both design codes. Since the most used reinforcement grade is $420 \mathrm{MPa}$ in Turkey, measured to predicted results are grouped according to steel grade of $420 \mathrm{MPa}$. Again, TS500 [1] shear strength predictions for transverse reinforcement grades equal to or lower than 420 $\mathrm{MPa}$ are more reliable than ACI318-19 [2] shear strength estimations, although the contribution of stirrups is considered via the same equations in both design codes. Shear strength predictions of both design codes again overestimated the measured 
shear strengths with average normalized ratios of 0.86 for TS500 [1] and 0.74 for ACI318-19 [2] for transverse steel grade above $420 \mathrm{MPa}$.

The last reliability check for design codes' shear strength predictions is performed by investigating the results in terms of longitudinal reinforcement ratios and stirrup spacings (Fig. 5). Although longitudinal reinforcement ratio is not used in the shear strength equation of TS500 [1], it is used in the concrete contribution to the shear strength equation of ACI318-19 [2]. It is also experimentally-observed that longitudinal reinforcement has dowel action effects on the shear strength of RC members. In both design codes at the lap splice zones, the longitudinal reinforcement ratio is limited to $3.0 \%$. The average of normalized values for TS500 [1] predictions is 0.94 whereas it is 0.80 in the estimations of ACI318-19 [2] for specimens with longitudinal reinforcement ratios below $3.0 \%$, which can be explained as the reliability of the concrete contribution approach in TS500 [1]. Both design codes overestimate the measured shear strengths with the longitudinal reinforcement ratio above $3.0 \%$. Since in seismic design codes, it is not allowed to use higher values for stirrup spacing, transverse reinforcing bar spacing below or equal to $200 \mathrm{~mm}$ is only investigated herein. Although both of the design codes overestimated measured shear strengths for column specimens having stirrup spacing below or equal to $200 \mathrm{~mm}$, the average of normalized ratios is 0.92 for TS500 [1] whereas it is 0.80 for ACI31819 [2].

As the last investigation within the scope of this study, regression analyses were carried out for 57 specimens that are studied to represent the relationship between design code predictions and test results. The $\mathrm{R}^{2}$ and mean normalized RMSE values for TS500 [1] and ACI318-19 [2] are presented in Table 2. The $\mathrm{R}^{2}$ values for TS500 [1] is 0.85 and 0.89 for ACI318-19 [2], while mean normalized RMSE values for TS500 [1] is 46\% and 65.6\% for ACI318-19 [2], representing that the abnormality in TS500 [1] predictions from the test results are less than ACI318-19 [2] estimations.
Table 2. Comparison of statistical results obtained from design codes

\begin{tabular}{lcc}
\hline Design codes & $\mathrm{R}^{2}$ & Mean normalized RMSE \\
\hline TS 500 [1] & 0.85 & $46.0 \%$ \\
ACI318-19 [2] & 0.89 & $65.6 \%$ \\
\hline
\end{tabular}

\section{Conclusion}

Shear strength predictions of current design codes (TS500 [1]; ACI318-19 [2]) were compared with experimentally-measured shear strength results of $57 \mathrm{RC}$ column specimens within the scope of this study. The contribution of concrete and transverse reinforcement to shear strength was also investigated in both design codes. Correlation between test results and design code predictions was conducted in terms of key parameters; shearspan-to-depth ratio, axial load ratio, concrete compressive strength, transverse reinforcement yield strength, longitudinal reinforcement ratio, and transverse reinforcing bar spacing. During the investigation of the main parameters, $\mathrm{RC}$ column specimens collected from the previous studies were classified into two groups for evaluating the reliability of design codes per critical limits that help predict the behavioral response of $\mathrm{RC}$ columns. The average of the measured to predicted shear strength ratios and their coefficient of variations are summarized in Table 3. In most of the cases, the mean values of normalized ratios for TS500 [1] are more close to the uniformity compared to the predictions using the equation in ACI318-19 [2]; however, the coefficient of variations is smaller in the predictions by the equation in ACI318-19 [2]. Although ACI318-19 [2] is published in 2019 and expected to have more accurate results, TS-500 [1] shear strength predictions provide more reliable results. Since the shear strength equation in ACI318-19 [2] considers a higher level of concrete contribution, and olddated test data, which was supposed to be poured with old-fashioned conditions, has been used within the scope of this study, the shear strength equation in TS-500 [1] seems to be more accurate compared to the equation in ACI318-19 [2]. 
Table 3. Summary of $\mathrm{V}_{\text {Test }} / \mathrm{V}_{\text {Predicted }}$ ratios in terms of main parameters

\begin{tabular}{|c|c|c|c|c|c|c|}
\hline \multirow{2}{*}{ Main parameters } & \multirow{2}{*}{ Group limits } & \multirow{2}{*}{$\begin{array}{l}\text { Total \# of } \\
\text { specimens }\end{array}$} & \multicolumn{2}{|c|}{ According to TS500 [1] } & \multicolumn{2}{|c|}{ According to ACI318-19 [2] } \\
\hline & & & Mean & Cov & Mean & Cov \\
\hline \multirow{2}{*}{ Shear-span-to-depth ratio $(a / d)$} & $a / d \leq 3.0$ & 23 & 1.01 & 0.20 & 0.85 & 0.14 \\
\hline & $a / d>3.0$ & 34 & 0.86 & 0.19 & 0.75 & 0.15 \\
\hline \multirow{2}{*}{ Axial load ratio $\left(P / A_{g} f_{c}\right)$} & $P / A_{g} f_{c}{ }^{\prime} \leq 35 \%$ & 53 & 0.90 & 0.22 & 0.79 & 0.19 \\
\hline & $P / A_{g} f_{c}{ }^{\prime}>35 \%$ & 4 & 1.15 & 0.23 & 0.78 & 0.26 \\
\hline \multirow{2}{*}{$\begin{array}{l}\text { Concrete compressive strength } \\
\left(f_{c}\right)\end{array}$} & $f_{c}^{\prime} \leq 30 \mathrm{MPa}$ & 36 & 0.99 & 0.18 & 0.81 & 0.16 \\
\hline & $f_{c}^{\prime}>30 \mathrm{MPa}$ & 21 & 0.81 & 0.25 & 0.75 & 0.24 \\
\hline \multirow{2}{*}{$\begin{array}{l}\text { Transverse reinforcement } \\
\text { yield strength }\left(f_{y w}\right)\end{array}$} & $f_{y w} \leq 420 \mathrm{MPa}$ & 36 & 0.95 & 0.22 & 0.81 & 0.18 \\
\hline & $f_{y w}>420 \mathrm{MPa}$ & 21 & 0.86 & 0.23 & 0.74 & 0.21 \\
\hline \multirow{2}{*}{$\begin{array}{l}\text { Longitudinal reinforcement } \\
\text { ratio }\left(\rho_{l}\right)\end{array}$} & $\rho_{l} \leq 3.0 \%$ & 50 & 0.94 & 0.20 & 0.80 & 0.18 \\
\hline & $\rho_{l}>3.0 \%$ & 7 & 0.78 & 0.35 & 0.69 & 0.29 \\
\hline \multirow{2}{*}{$\begin{array}{l}\text { Transverse reinforcing bar } \\
\text { spacing }(s)\end{array}$} & $s \leq 200 \mathrm{~mm}$ & 46 & 0.92 & 0.25 & 0.80 & 0.20 \\
\hline & $s>200 \mathrm{~mm}$ & 11 & 0.92 & 0.10 & 0.75 & 0.15 \\
\hline
\end{tabular}

It can be realized that TS500 [1] shear strength predictions underestimate the shear strength of RC columns with a shear-span-to-depth ratio below 3.0, considering the being close to the measured shear strength values of RC column specimens, using TS500 [1] in terms of shear-span-to-depth ratio seems more consistent. The shear strength equation in TS500 [1] provides a mean value of 0.90 for the RC columns specimens with an axial load of $35 \%$ which is under the axial load limits defined in the Turkish Building Seismic Code (TBSC-2018) [23] that shows the consistency of the shear strength equation in TS500 [1]. When the shear strength equations are scrutinized in terms of concrete compressive strength, transverse reinforcement yield strength, longitudinal reinforcement ratio, and transverse reinforcing bar spacing, it is obvious that shear strength predictions obtained from the equation in TS500 [1] have mean values close to 1.0 compared to the shear strength predictions obtained from the equation in ACI318-19 [2].

The aforementioned results again manifest the reliability of the shear strength equation in TS500 [1] although having diversity in coefficient of variations. Furthermore, regression analyses were carried out for 57 specimens that are investigated to show the correlation between design code predictions and test results. The $\mathrm{R}^{2}$ value for TS500 [1] is 0.85 , whereas it is 0.89 for ACI318-19 [2], with mean normalized RMSE values of $46 \%$ and 65.6\% for TS500 [1] and ACI318-19 [2], respectively, indicating that the deviation in TS500 [1] predictions from the test results are less than ACI318-19 [2] estimations.

Further studies need to be conducted to enlarge specimen numbers. Increasing specimen number will help to introduce alternative equations according to developed statistical analysis methods. The correlation between the experimental results and the alternative equation will be aimed to have a good fit. Additionally, since failure types of RC columns also affect the shear strengths of columns, design code predictions should be investigated in terms of failure types. Current design code equations need to be enhanced by considering the results of the intended statistical studies with a broad range of experimental data to obtain better correlations with test results.

\section{Declaration of conflicting interests}

The author(s) declared no potential conflicts of interest with respect to the research, authorship, and/or publication of this article. 


\section{Acknowledgments}

This work was supported by the Harran University Scientific Research Projects Coordinator (HUBAK), Grant No: 21126.

\section{References}

[1] TS 500: Requirements for design and construction of reinforced concrete structures, TSE (Turkish Standards Institute), Ankara, Turkey, 2000.

[2] ACI 318-19: Building code requirements for structural concrete and commentary; American Concrete Institute, Farmington Hills, MI, USA, 2019.

[3] Wight JK, Sozen MA. Shear strength decay in reinforced concrete columns subjected to large deflection reversals, Report to The National Science Foundation, Civil Engineering Studies, Structural Engineering Series No. 403 University of Illinois, Urbana-Champaign, 1973.

[4] Priestley MJN, Verma R, Xiao Y (1994) Seismic shear strength of reinforced concrete columns. Journal of Structural Engineering 120(8): 23102329.

[5] Sasani M. Shear strength and deformation capacity models for RC columns. 13th World Conference on Earthquake Engineering, 2004, Vancouver, British Columbia, Canada.

[6] Aval SBB, Ketabdari H, Gharebaghi SA (2017) Estimating shear strength of short rectangular reinforced concrete columns using nonlinear regression and gene expression programming. Structures 12: 13-27.

[7] ABAQUS A. 6.13 Analysis user's manual. 2013.

[8] ACI 318-11: Building code requirements for structural concrete, American Concrete Institute, Farmington Hills, MI, USA, 2011.

[9] Eurocode 2: Design of concrete structures, European Committee for Standardization, 2008.

[10] Ketabdari H, Karimi F, Rasuoli M (2020) Shear strength prediction of short circular reinforcedconcrete columns using soft computing methods. Advances in Structural Engineering 23(14): 30483061 .
[11] ACI 318-14: Building code requirements for structural concrete, American Concrete Institute, Farmington Hills, MI, USA, 2014.

[12] ASCE-ACI Committee 426 (1973) The shear strength of reinforced concrete members. Journal of the Structural Division 99(ST6): 1148-1157.

[13] Kakavand MRA, Sezen H, Taciroglu E (2021) Data-driven models for predicting the shear strength of rectangular and circular reinforced concrete columns. ASCE Journal of Structural Engineering 147 (1): 04020301.

[14] Kokusho S. Report by Building Research Institute, March, 1964.

[15] Kokusho S, Fukuhara M, Report by Kokusho Lab., Tokyo Industrial University, 1965

[16] Ikeda A, Strength and deformation structure, by Muto, Maruzen Co. Ltd., 1965.

[17] Umemura H, Endo T. Report by Umemura Lab, Tokyo University, 1970.

[18] Ohue M, Morimoto H, Fujii S, Morito S (1985) The behavior of RC short columns failing in splitting bond-shear under dynamic lateral loading. Transactions of the Japan Concrete Institute 7(1): 293-300.

[19] Saatcioglu M, Ozcebe G (1989) Response of reinforced concrete columns to simulated seismic loading. Structural Journal 86(1): 3-12.

[20] Esaki F. Reinforcing effect of steel plate hoops on ductility of R/C square columns. 11th World Conference on Earthquake Engineering, 1996, Pergamon, Elsevier Science.

[21] Lynn AC, Moehle JP, Mahin SA, Holmes WT (1996) Seismic evaluation of existing reinforced concrete columns. Earthquake Spectra 12(4): 715 739.

[22] Sezen H, Moehle JP. Seismic behavior of shearcritical reinforced concrete building columns. Seventh US National Conference on Earthquake Engineering, 2002, Earthquake Engineering Research Institute, Boston, MA.

[23] TBSC 2018: Turkish Building Seismic Code, Prime Ministry, Disaster and Emergency Management Presidency (AFAD), Ankara, Turkey, 2018 